\title{
Velázquez’s Democritus: Global Disillusion and the Critical Hermeneutics of a Smile
}

\author{
JAVIER BERZAL DE DIOS
}

Western Washington University

Velázquez's Democritus (ca. 1630) presents a unique encounter: not only are there few depictions in which the Greek philosopher appears with a sphere that shows an actual map, but Velázquez used a court jester as a model for Democritus, thus placing the philosopher within a courtly space. When we study the painting in relation to the literary interests of the Spanish Golden Age and its socio-political circumstances, we can see the figure of Democritus as far from just another instantiation of a conventional trope. The philosopher's smile and his crepuscular globe entrap the viewer in a semiotic game with pedagogical and ethical goals. While the scholarship on the painting has dwelt extensively on the identification of the figure, this essay moves beyond the superficial aspects of subject identity in order to explore how the painting articulates and requests a profoundly philosophical engagement. I thus examine Democritus in relation to contemporary literary and philosophical themes, many of which were present in Velázquez's own personal library: the period's understanding of the philosopher, cartographic spheres, and treatises on laughter. Considered in this manner, Velázquez's figure is not responding to the folly of humanity in general, as is commonly the case in representations of the philosopher, but is rather presented through a courtly prism in which conquest, geography, and politics are inescapably interrelated. Velázquez's Democritus emphasizes the philosophical and moral qualities of a learned and decorous laughter, which performs a critical and ethical role framed by Spain's political difficulties.

Le Démocrite de Velázquez (c. 1630) représente une rencontre exceptionnelle entre divers éléments. En effet, rares sont les représentations montrant le philosophe grec avec un globe terrestre dessinant une carte géographique crédible; plus encore, Velázquez a pris comme modèle un bouffon de cour, plaçant ainsi le philosophe dans le contexte courtisan. Lorsqu'on examine le tableau en relation avec l'actualité littéraire de lâge d’or espagnol et dans son contexte sociopolitique, la représentation de Démocrite s'avère ici bien plus qu'un trope conventionnel. De fait, le sourire du philosophe et son globe prennent le spectateur au piège d'un jeu sémiotique dont les objectifs sont pédagogiques et éthiques. Tandis que les chercheurs se sont surtout penchés sur l'identification du personnage, cet article cherche à aller au-delà de la reconnaissance de l'identité du sujet, et se donne pour but d'explorer la manière dont le tableau définit et requiert un engagement profondément philosophique. J'examine donc Démocrite dans ses rapports aux thèmes littéraires et philosophiques de son époque, que lon retrouve en grande partie dans la bibliothèque de Velázquez lui-même: en particulier, la perception que l'on avait alors de ce philosophe, l'histoire des globes terrestres, et les traités sur le rire. Dans cette perspective, ce tableau de Velásquez ne fait pas référence à la folie inhérente de l'humanité, ce qui est généralement le cas dans les représentations du philosophe, mais cooemnte plutôt le monde courtisan dans lequel conquête, géographie et politique sont irrémédiablement liés. Le Démocrite 
met ainsi en lumière les qualités philosophiques et morales d'un rire savant et bienséant, qui tient un rôle critique et éthique dans le contexte des difficultés politiques de l'Espagne.

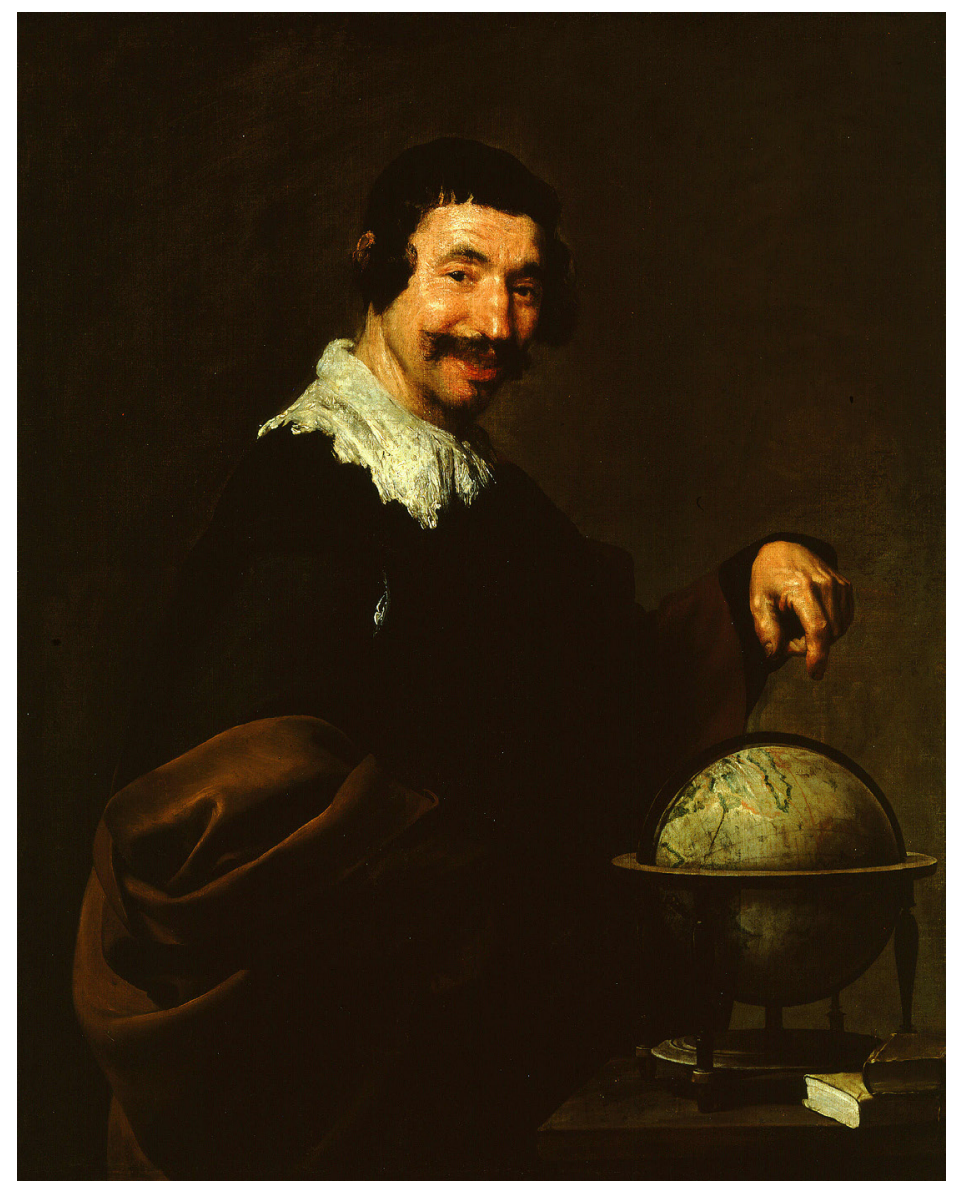

Fig. 1 Diego Velázquez, Democritus, ca. 1630. Oil on canvas. 101 x $81 \mathrm{~cm}$.

Musée des Beaux-Arts, Rouen.

CC emocritus used to laugh, and Heraclitus to weep, at everything that happened," wrote Laurent Joubert in his famous 1579 Treatise on Laughter, reiterating a firmly established trope. ${ }^{1}$ The dichotomy between Democritus laughing at the folly of humanity and Heraclitus desperately crying in sorrow was a motif that originated in classical times, later permeating

1. Laurent Joubert, Treatise on Laughter (Alabama: Alabama University Press, 1980), 99. 
early modern European culture. ${ }^{2}$ The visual arts make plain the prominence of Democritus in the sixteenth and seventeenth centuries, presenting the thinker as a readily identifiable figure who appears holding or pointing to a globe as he smiles or laughs. Whether alone or accompanied by Heraclitus, the philosopher appears in paintings by artists such as Donato Bramante, Peter Paul Rubens, Jusepe de Ribera, Hendrick Ter Brugghen, Jan van Bylert, Cornelis Cornelisz, Jacob Jordaens, Januarius Zick, and Salvator Rosa.

This essay presents a close reading of Diego Velázquez's ca. 1630 Democritus (fig. 1), paying special attention to how the figure's smile and pointing gesture relate to the social, cultural, and political circumstances of the period. The painting is itself exceptional: not only are there few depictions in which the Greek philosopher appears with a sphere that shows a map, as is the case in Velázquez's painting, but the image is remarkable in its use of a court jester as a model for Democritus. Despite its uniqueness, the scholarship has either dwelt on the identification of the figure or glossed over the painting as yet another token in a long and general list of artworks portraying the ancient thinker. Exploring the noted "complex web of meaning" woven by Velázquez in his paintings of courtly entertainers, ${ }^{3}$ my intent here is to move beyond the superficial aspects of subject identity in order to examine how the painting's particularities articulate and request a profoundly philosophical engagement. Being attentive to the period understanding of the philosopher, spheres, and laughter, I study the many layers of significance found in Velázquez's painting in relation to contemporary literary themes and pedagogical traditions. ${ }^{4}$ In this sense, and unlike other paintings of Democritus, we can understand Velázquez's figure not as scoffing at the folly of humanity in general but as presented through a courtly prism that accentuates geo-political concerns. Much like the literary

2. Cora E. Lutz, "Democritus and Heraclitus," The Classical Journal 49.7 (1954): 309-14; Fernando Bouza, "Modern Rogues and Ancient Philosophers in Philip IV's Court: Three Laughs, Two Imitations and a Funny Face," in Velázquez's Fables: Mythology and Sacred History in the Golden Age, ed. J. Portús Pérez (Madrid: Museo del Prado, 2007), 214-15, exhibition catalogue; John L. Lepage, The Revival of Antique Philosophy in the Renaissance (New York: Palgrave, 2012), 81-136; Matthew Steggle, Laughing and Weeping in Early Modern Theatres (Burlington: Ashgate, 2007).

3. Alfonso E. Pérez Sánchez, "Velázquez and the Baroque Portrait," in The Spanish Portrait from El Greco to Picasso, ed. Javier Portús (Madrid and London: Museo Nacional del Prado/Scala, 2004), 184.

4. Braden Frieder, "Telling the Truth in Baroque Spain: Past and Present in the Jester Portraits of Velázquez," Discoveries: South-Central Renaissance Conference News and Notes 21 (2004): 5-18. 
figures of the Spanish Golden Age, Velázquez emphasizes the philosophical and moral qualities of a learned and decorous humour, which performs a critical and ethical role in a period marked by imperial challenges.

\section{Democritus}

Standing in front of Democritus, the viewer experiences the sense of immediacy and presence that characterizes Velázquez's portraiture in general. ${ }^{5}$ Set against a dark maroon background, which effectively blends with his black doublet, the well-illuminated face of the philosopher appears as the definite centre of attention - a focus aided by a painterly white lace collar. Democritus meets the viewer with a captivating smile. It is a smile, not a smirk or a grin; much less a simper. Democritus's eyes are piercing and direct, framed by creased eyelids. The wrinkles around his eyes resonate with those around the mouth, articulating a genuine smile. ${ }^{6} \mathrm{~A}$ sincere reaction, the smile is casual and believable. Even if there is sense of theatricality in the presentation of the subject, Velázquez ensures we do not encounter an exaggerated or histrionic act. ${ }^{7}$ This is not the performed smile of an actor. There is something affable about Democritussomething familiar, intimate.

With his right arm akimbo, Democritus strikes and holds a jaunty pose. The glossy quality of his face echoes the illuminated texture of the hand, leading our attention down toward a sphere. The smile attracts the viewers; the hand redirects their gaze. The sphere rests on a table next to two books that, much like Democritus's right elbow, are pushed towards the picture plane. The sphere

5. On the issue of immediacy, presence, and proximity in Velázquez's portraiture see Frieder, 166-67.

6. Scientists will later codify how a genuine smile requires flexing the facial muscles that raise the cheeks and create lines around the eyes (orbicularis oculi), and not just those around the lips (zygomatic major), but artists like Velázquez clearly understood this phenomenon through observation. A genuine smile became later known as a Duchenne smile, named after the French physician Guillaume Duchenne de Boulogne (1806-75). Guillaume Duchenne, Mecanisme de la Physionomie Humaine (Paris: Jules Renouard Libraire, 1862). Reprinted as The Mechanism of Human Facial Expression, trans. R. A. Cuthbertson (Cambridge: Cambridge University Press, 1990). See also Bridget M. Waller et al., "Intramuscular Stimulation of Facial Muscles in Humans and Chimpanzees: Duchenne revisited," Emotion 6.3 (2006): 367-82; Marc Mehu et al., "Smiles when Sharing," Evolution and Human Behavior 28.6 (2007): 415-22.

7. On the difference between decorous and histrionic gestures in early modern Spanish painting and aesthetic theory see Juan Luis González García, Imágenes sagradas y predicación visual en el Siglo de Oro (Madrid: Akal, 2015), 172-89. 
and the books suggest a tentative location: a study, a place of learning. The philosopher's focused gaze and bonhomie seem to present a poised challenge, creating a learned and sequestered dialogue. This is itself a philosophical reflection, for each viewer who encounters Democritus must make a choice: to accept or deny the buoyant philosopher's insight. In front of the painting, the viewer ponders not only laughter in relationship to his or her life but also the figure of the philosopher within the history of ideas.

Although not much is known about the circumstances regarding its commission, the Democritus does not appear to have been a royal assignment. The painting was included in the 1692 sale of Marquis de Carpio's collection (the Marquis was a nephew of the Count-Duke of Olivares, and Philip IV's favourite). Democritus might have been later allotted to the Marquis's gardener as payment for overdue salaries. ${ }^{8}$ Whether commissioned by the Marquis or subsequently purchased by him, the original audience (and owner) was a wellsituated member of the court.

Interestingly, Velázquez reused a previously existing painting for his Democritus, which makes accurate dating difficult. X-rays of the painting have shown that the man originally was holding a glass rather than pointing to a globe. An anonymous period copy of the painting prior to Velázquez's changes likely shows the original composition, the Man with a Glass at Toledo, Ohio. ${ }^{9}$ The sitter of the painting appears to be renowned court Jester Pablo de Valladolid, ${ }^{10}$ of whom Velázquez would paint a full figure painting ca. 1636, today housed at the Prado. The idea of painting (or in this case, re-painting) Democritus has been seen as a response to the well-documented contemporary interest in the Greek philosopher as manifested in artworks like Peter Paul Rubens's 1603 Democritus

8. José López-Rey, Velázquez: The Artist as Maker with a Catalogue Raisonné of His Extant Works (Lausanne-Paris: Bibliothèque des Arts, 1979), 278.

9. "Chroniques du Laboratoire. Notes sur les radiographies de deux tableau appartenant aux Musée de Pau et du Rouen," Bulletin du Laboratoire du Musée du Louvre 9 (1964): 50-53. Jonathan Brown locates the changes in the late 1630s; see Brown, Velázquez: Painter and Courtier (New Haven and London: Yale University Press, 1986), 57; López-Rey, 278.

10. On this identification, see José Moreno Villa, Locos, enanos, negros y niños palaciegos. Gente de placer que tuvieron los Austrias en la corte española desde 1563 a 1700 (Mexico: Casa de España, 1939), 74. Bouza has remained somewhat skeptical of this identification and its interpretative effect; see his "Modern Rogues and Ancient Philosophers," 207-08. Nonetheless, I believe the physiognomic similarities between the sitter in the Democritus and the ca. 1626 portrait of Pablillo de Valladolid in the Prado cannot be discarded as marginal or coincidental. 
and Heraclitus (fig. 2), painted in Valladolid. ${ }^{11}$ Unlike other iterations of the philosopher, Velázquez presents Democritus without his crying counterpart, and it seems that such a companion painting was never composed. ${ }^{12}$

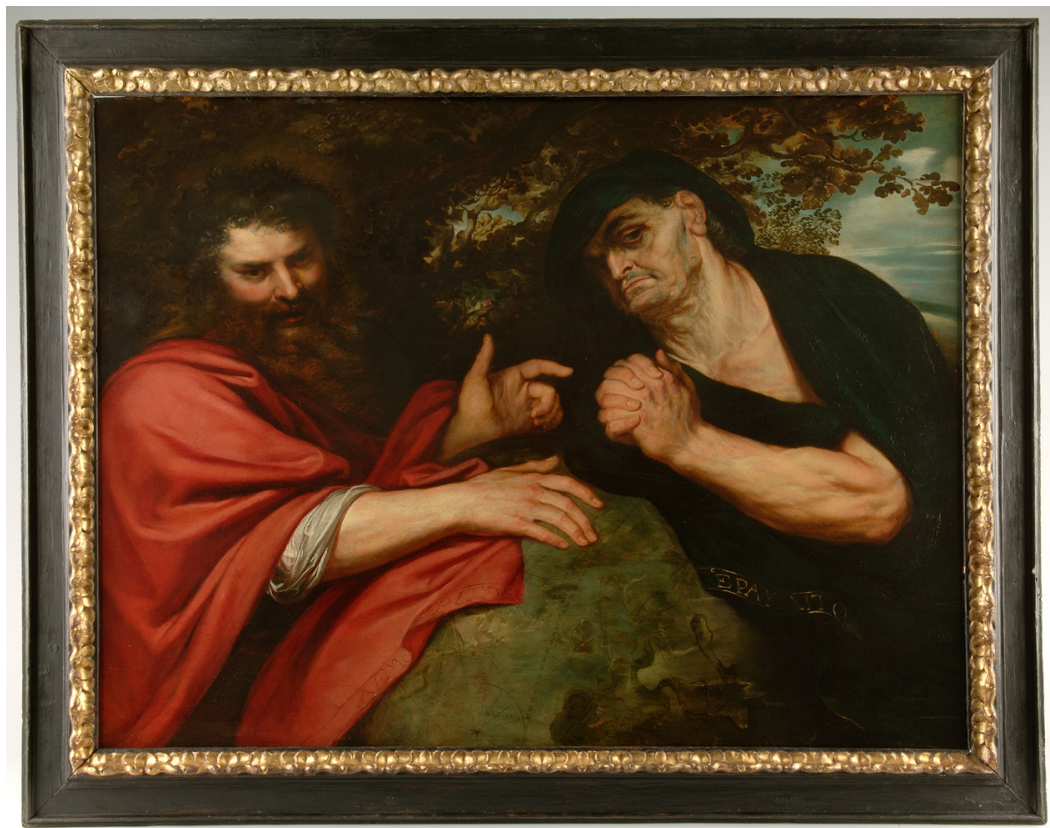

Fig. L Peter raul Kubens, Vemocritus and Heracıtus, IoUs. Uil on panel.

$95 \times 125 \mathrm{~cm}$. Museo Nacional de Escultura, Valladolid.

The popular trope of the laughing Democritus and the crying Heraclitus is rooted in the study of classical texts by early modern scholars. Medieval sources on the philosopher were rather limited in number and remained obscure. ${ }^{13}$ Dante reduced the Greek philosopher to someone who believed in the randomness

11. On the issue of artistic rivalry and emulation, see Javier Portús, "Velázquez as History Painter: Rivalry, Eminence and Artistic Consciousness," in Velázquez's Fables: Mythology and Sacred History in the Golden Age, ed. J. Portús Pérez (Madrid: Museo del Prado, 2007), 50-61.

12. Francisco Rico, “Los filósofos de Velázquez o el Gran Teatro del Mundo,” El Paseante 18-19 (1991): 50-61. Also published in El Siglo de Oro de la pintura española, ed. Javier Portús (Madrid: Fundación Amigos del Museo del Prado/Mondadori, 1991), 345-58.

13. Ángel María García Gómez, The Legend of the Laughing Philosopher and Its Presence in Spanish Literature, 1500-1700 (Córdoba: Servicio de Publicaciones, Universidad de Córdoba, 1984), 40. 
of the world, disregarding or perhaps unaware of the trope of laughter..$^{14}$ It would be Renaissance humanism that recovered the figure of Democritus in its complexity. Ángel García Gómez, in his study of the presence of Democritus in early modern literature, associates the emergence of Democritus with two works: the 1495 Stultitia et miseria hominum of Marsilio Ficino, and Riso de Democrito et Pianto de Heraclito, written by Antonio Fregoso and published in $1511 .{ }^{15}$ These writers engaged not with the philosophy of Democritus but with the recurrent theme of Democritus's laughter as opposed to Heraclitus's weeping. The motif itself had well-established roots. Cicero, for example, often engaged with the ethical and scientific theories of Democritus, including his laughter, ${ }^{16}$ and in Horace's Epistle II the follies of humanity offer Democritus more "strange sights than the actor." ${ }^{17}$ Lucian makes use of the trope for comic purposes in his Philosophies for Sale: Zeus and Hermes organize an auction in a failed attempt to sell various philosophers, including the weeping Heraclitus and laughing Democritus. ${ }^{18}$ And Juvenal's Satire $X$, a central and widely quoted classical source, asks the reader to choose between two wise men: one who laughs and one who cries. ${ }^{19}$

14. "Democrito che 'l mondo a caso pone," in Dante, Inferno, canto 4, v. 136.

15. García Gómez, 68, 74. See also Paul Oskar Kristeller, I pensiero filosofico di Marsilio Ficino (Florence: Le Letter, 1988), 316-17; Bouza, "Modern Rogues and Ancient Philosophers," 214. On Ficino and the Democritus-Heraclitus trope in art, see Meredith Gill, Augustine in the Italian Renaissance: Art and Philosophy from Petrarch to Michelangelo (Cambridge: Cambridge University Press, 2005), 24-26; Christian Kleinbub, Vision and the Visionary in Raphael (University Park: Pennsylvania University Press, 2011) 64-69.

16. On the issue of humour see Cicero, De oratore 2.58-62, On his philosophy and science see, e.g., Cicero, Academica, 44, De Finibus, 1:18, 2:102.

17. "Si foret in terris, rideret Democritus, seu diuersum confusa genus panthera camelo siue elephans albus uolgi conuerteret ora; spectaret populum ludis attentius ipsis ut sibi praebentem nimio spectacula plura; scriptores autem narrare putaret asello fabellam surdo. Nam quae peruincere uoces eualuere sonum, referunt quem nostra theatra?" Horace's Epistle II, 1.194-201. For a recent bilingual edition, see The Epistles of Horace, trans. D. Ferry (New York: Farrar, Straus and Giroux, 2002), 124.

18. See also Lutz, "Democritus and Heraclitus."

19. "Iamne igitur laudas quod de sapientibus alter / ridebat, quotiens a limine mouerat unum / protuleratque pedem, flebat contrarius auctor?" Juvenal, “Satire X." See Juvenal and Persius, trans. S. Morton (Cambridge, MA: Harvard University Press, 2004), 364-98. See also Catherine Keane, Juvenal and the Satiric Emotions (Oxford: Oxford University Press, 2015). 
As Fernando Bouza has shown, the trope of the two philosophers was quite alive in early modern Spain, especially following the 1554 publication of Antonio Fregoso's Doi filosofi in Valladolid by Alonso de Lobera, and later reified by Antonio López de Vega’s 1641 Heráclito y Demócrito de nuestro siglo and other pictorial and manuscript works. ${ }^{20}$ In seventeenth-century Spain, the most influential interpretation of the two philosophers was that of Seneca, who encountered positive philosophical aspects in Democritus and his omnipresent laughter. ${ }^{21}$ Seneca's juxtaposition of a laughing Democritus and a crying Heraclitus would have been known to early modern readers with the dissemination of On Tranquility of Mind, a text published in Madrid in 1627 by Fernandez de Navarrete and dedicated to the Count-Duke of Olivares. In this text, the Roman stoic thinker sides with Democritus over Heraclitus:

\begin{abstract}
We should imitate Democritus rather than Heraclitus. For the latter used to weep whenever he appeared in public, but the former laughed: to one everything which we do seemed to be foolishness, to the other, misery [...] he who laughs at the human race [...] leaves something still to be hoped for; the latter stupidly weeps over what he despairs of being able to correct. $^{22}$
\end{abstract}

20. Bouza, "Modern Rogues and Ancient Philosophers," 215-17. See also Jeremy Robbins, "Scepticism and Stoicism in Spain: Antonio López de Vega’s Heráclito y Demócrito de Nuestro Siglo," in Culture and Society in Habsburg Spain, ed. N. Griffin et al. (London: Tamesis, 2001), 137-52.

21. "Heraclitus quotiens prodierat et tantum circa se male uiuentium, immo male pereuntium uiderat, flebat, miserebatur omnium qui sibi laeti felicesque occurrebant, miti animo, sed nimis inbecillo: et ipse inter deplorandos erat. Democritum contra aiunt numquam sine risu in publico fuisse; adeo nihil illi uidebatur serium eorum quae serio gerebantur. Vbi istic irae locus est? aut ridenda omnia aut flenda sunt." L. Annaeus Seneca, de Ira, 2:10. For an English edition see Seneca, Moral Essays, vol. 2, trans. J. Basone (Cambridge, MA: Harvard University Press, 1932). The Spanish edition was published as Séneca, Siete Libros (Madrid: Imprenta Real, 1627).

22. "In hoc itaque flectendi sumus, ut omnia vulgi vitia non invisa nobis sed ridicula videantur et Democritum potius imitemur quam Heraclitum. Hic enim, quotiens in publicum processerat, flebat, ille ridebat ; huic omnia quae agimus miseriae, illi ineptiae videbantur. [...] Adice quod de humano quoque genere melius meretur qui ridet illud quam qui luget; ille ei spei bonae aliquid relinquit, hic autem stulte deflet quae corrigi posse desperat." Seneca, On Tranquillity of Mind, 14:10-xv.3. Translation from Basone in Seneca, Moral Essays, 272. 
It is noteworthy that Seneca interprets Democritus not as a philosopher who simply derides the world but as a thinker who is invested in ethical improvement. By doing so, Seneca's interpretation befits Democritus's own philosophy. Democritus's attitude is not towards humanity in general but towards humanity's irrational assumptions. He presents a moral stand through which individuals ought to be critical of sense data, interpreting and evaluating their perceptions. $^{23}$

Democritus's original theories were strictly materialistic. He posited, along with his teacher Leucippus, that the world was made up of indivisible, indestructible atoms. In his epistemological theories, Democritus emphasizes that sense perception is subjective, famously stating, "By convention there is sweet, by convention there is bitter, by convention hot and cold, by convention color but in reality atoms and void." 24 Despite this subjectivity, Democritus argues that there are two types of thought, which he calls "obscure" and "genuine." 25 The former depends merely on perception and is inadequate; the latter is a rational process in which sense perception is analyzed in order to understand the causes and relationships that govern the sense data. ${ }^{26}$ Politically, Democritus defended moderation and the values of education. ${ }^{27}$

23. The Atomists: Leucippus and Democritus, trans. and commentary by T. Taylor (Toronto: University of Toronto Press, 1999), 227.

24. Taylor, 9.

25. Mi-Kyoung Lee, Epistemology after Protagoras: Responses to Relativism in Plato, Aristotle, and Democritus (Oxford: Oxford University Press, 2005), 232.

26. "Democritus used to say that "he prefers to discover a causality rather than become a king of Persia," wrote Sextus Empiricus, ca. 200 CE, in Adversus Mathematicos, Fr. 118. Genuine knowledge (gnesie gnome) is the reason why Sextus Empiricus does not consider Democritus a skeptic, as argued by Lee (229) and Taylor (191-92). Nevertheless, other thinkers, in both the ancient and the early modern worlds, did consider Democritus to be a skeptic whose theories ultimately lead to the impossibility of knowledge and freedom. "The basic assumption of the absolute reality of atoms and their movement through the void allows the content of sensory perception to be considered only as appearance. But, at the same time, this appearance is what is true as it shows itself. [...] Genuine perception, therefore, always allows us to assume the sole reality of the atoms and the void in all apparent sense data." HansGeorg Gadamer, The Beginning of Knowledge (New York and London: Continuum, 2003), 97-98.

27. See Daniel Graham, The Texts of Early Greek Philosophy: The Complete Fragments and Selected Testimonies of the Major Presocratics (Cambridge: Cambridge University Press, 2010), chapter 4, esp. commentary on 684. See also Jorgen Mejer, "Democritus and Democracy," Apeiron 37.1 (2004):1-9; J. F. Procopé, "Democritus on Politics and the Care of the Soul," Classical Quarterly 39 (1989): 307-31 
Despite the pervasive presence of images of Democritus in the seventeenth century, and the popularity of texts referring to the philosopher in Spain, ${ }^{28}$ Velázquez's painting was once called The Geographer. ${ }^{29}$ Given the main attributes-pointing, mirth, and the globe-one has to wonder why such a title would have been appended, and why it was not immediately seen as a depiction of Democritus (as the scholarship today widely upholds). It likely had to do with the trope losing its popularity in the following centuries or its reception by an audience unaware of the specific and pre-existing pictorial conventions regarding the Greek philosopher. Be that as it may, as Francisco Rico points out, it would have been impossible for an educated seventeenth-century viewer to see this painting without immediately thinking of Democritus. ${ }^{30}$ It was a theme that clearly interested the Spanish court as well as the artistic and literary circles of Madrid in the 1620s and 1630s. Rubens painted two canvasses in 1635, representing Democritus and Heraclitus respectively, which hung in the Torre de la Parada (fig. 3). ${ }^{31}$ It has been hypothesized that Velázquez might have decided to alter the previously existing canvas depicting a jester as a response to Rubens's works. ${ }^{32}$ Furthermore, as scholars have noted, Velázquez himself

and the subsequent "Democritus on Politics and the Care of the Soul: Appendix," Classical Quarterly 40 (1990): 21-45.

28. Bérénice Vila Baundry, "In tristitia hilaris, in hilarete tristis: Lope de Vega y la figura de Demócrito y Heráclito," Escritura e Imagen 6 (2010): 87-112. See also Otis Green, Spain and the Western Tradition: The Castilian Mind in Literature from El Cid to Calderón, vol. 4 (Madison: University of Wisconsin Press, 1963), 125-45.

29. Werner Weisbach, "Der sogenannte Geograph von Velasquez und die Darstellungen des Demokrit und Heraklit," Jahrbuch der Preussischen Kunstsammlungen 4.9 (1928): 141-58. See also Matias Diaz Padron, El siglo de Rubens en el Museo del Prado (Madrid: Museo del Prado, 1995), 950, exhibition catalogue.

30. Rico, 51.

31. Rico, 51. See also Edgar Wind, "The Christian Democritus," Journal of the Warburg Institute 1.2 (1937): 180-82; Svetlana Alpers, "The Decoration of the Torre de la Parada," in Corpus Rubenianum Ludwig Burchard (book 9) (London and New York: Phaidon, 1971), 120-22, 134-36; Wolfram Prinz, "The Four Philosophers by Rubens and the Pseudo-Seneca in Seventeenth-Century Painting," The Art Bulletin 55.3 (Sept 1973): 410-28; Frances Huemer, "Rubens's Democritus and Heraclitus," Notes in the History of Art 28.3 (Spring 2009): 24-28; Paul Oppenheimer, Rubens: A Portrait (New York: Cooper Square, 2002), 180-82; Aneta Georgievska-Shine and Larry Silver, Rubens, Velázquez, and the King of Spain (Burlington: Ashgate, 2014), 1-11, 172-77.

32. Brown, Velázquez, 57; López-Rey, 42; Rico, 52-53. 
owned and thoroughly studied a text that explicitly mentions Democritus's incessant laughter, Giovanni Battista della Porta’s De humana physiognomonia. ${ }^{33}$

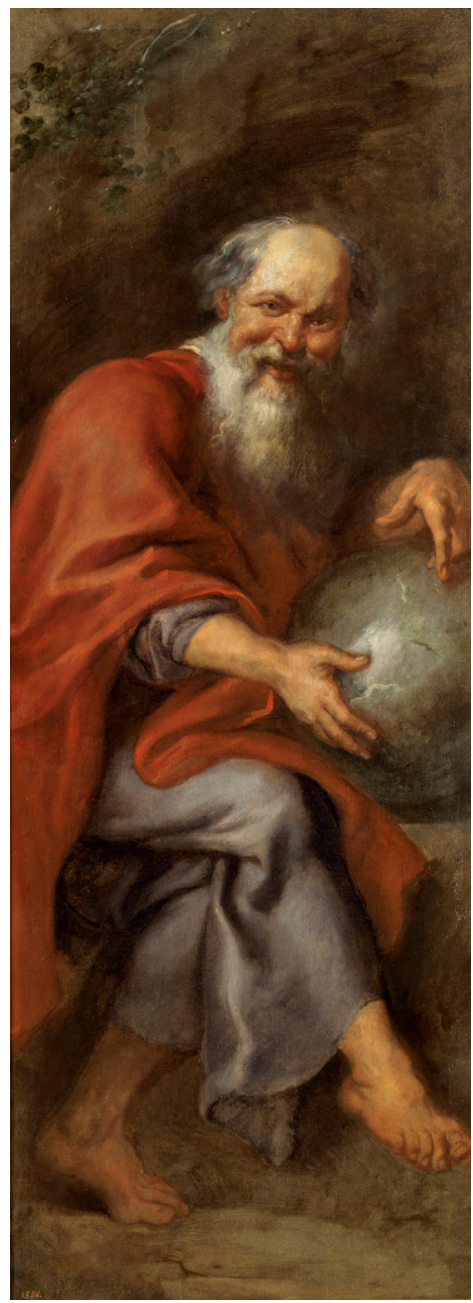

Fig. 3 Peter Paul Rubens, Democritus, 1636. Oil on canvas. 179 x $66 \mathrm{~cm}$. Museo del Prado, Madrid.

33. Giovanni Battista della Porta, Della fisionomia dell'huomo, book 2, chapter 18, "Del Riso." See also Pedro Ruiz Pérez, La Biblioteca de Velázquez (Sevilla: Consejeria de Cultura de la Junta de Andalucía, 1999), 90, exhibition catalogue; Alfonso Pérez Sánchez and Julián Gállego, Velázquez (New York: Metropolitan Museum of Art, 1989), 203, exhibition catalogue. 
Although, as previously mentioned, the scholarship today consistently agrees that the Velázquez's canvas depicts Democritus, it is worth considering briefly what qualities have (or could have) hindered the recognition of the philosopher, as these elements are themselves relevant to an interpretation of the painting. The decision to portray Democritus conspicuously clad in contemporary Spanish fashion, for example, establishes a degree of separation from the ancient philosopher-Rubens's paintings, in contrast, retain in the costuming a vague sense of classical temporality. The physiognomy of the individual in Velázquez's rendition also stipulates historical distance. In comparison with Rubens's depictions of Democritus, Velázquez's figure evokes a contemporary individual, which in itself is hardly new in an artist for whom the gods and philosophers of antiquity remained alive. ${ }^{34}$ Velázquez's paintings often have as a point of departure that which is present and known, ${ }^{35}$ which is truly the case with Democritus, in which not only clothing and physiognomy anchor the painting into a specific spatiotemporal location, but the materiality of the painting makes use of a previous portrait. The painting is not of an ancient Democritus whose laughter is a token lost in history. The connection to an actual jester seems a logical and even rather useful choice in subtly exploring the concept of laughter. As Bouza has argued, these sorts of transferences were not altogether uncommon in seventeenth-century Spain; nevertheless, the presence of the jester in the painting cannot easily be discarded as marginal nor can its analysis be deemed unnecessary. ${ }^{36}$ That period images of philosophers in painting and print convey at a general level "men enlightened by desengaño who had rejected worldly things" ${ }^{37}$ does not fully explain the particular and exceptional choices made by Velázquez in his Democritus.

To be attentive to Velázquez's pictorial approach entails moving beyond a putative hermeneutic framework ascribing a single and distinct subject

34. Rico, 52; Manuela Mena Marqués, "Velázquez en la Torre de la Parada," in Velázquez y Calderón: Dos genios de Europa, ed. Alcala-Zamora and Perez Sanchez (Madrid, Real Academia de la Historia, 2000), 101-55.

35. José Antonio Maravall, Velázquez y el espíritu de la modernidad (Madrid: Ediciones Guadarrama, 1960), 224. See also Moreno Villa, 74.

36. "[...] nor is such identification [of Pablillo de Valladolid] necessary, though in seventeenth-century Spain this sort of transference would have been nothing out of the ordinary." Bouza, "Modern Rogues and Ancient Philosophers," 208.

37. Bouza, "Modern Rogues and Ancient Philosophers," 218. 
matter; one must approach the web of meaning without enforcing a singular and transparent resolution. Democritus operates by addition rather than disjunction: its visual effectiveness is, to an important degree, generated by the layering of meanings. Not only does Democritus embrace a compound visual syntax; it also articulates the richness of meaning produced by the intertwining of Pablo de Valladolid and Democritus. In an attempt to categorize jester and dwarf portraits, Fernando Marías proposed the category of "servicio de bufones" as distinct from mere portraits of court entertainers. ${ }^{38}$ This genre presents a buffoon as an active individual engaged in an activity and focused on his or her object of attention. This, argues Marías, allowed the painter to present not simply the person but also his main occupation, known abilities, and other qualities. In Democritus, the jester's occupation and personhood remains. The painting retains, like other "servicio de bufones" portraits, an activity and an object of attention but, at the same time, it complicates the scene, as the object of attention belongs as much to the jester as to the ancient philosopher. This doubling reminds the viewers that one of the common activities for court jesters was precisely pretending to be someone else, to imitate. ${ }^{39}$

Yet the jester does not merely perform the part of Democritus the way an actor would play a role; he embodies the philosopher's attitude. Of course, there is nothing novel in painting images of actual people in place of ancient characters, but Velázquez's rather sophisticated maneuver is not quite as superficial as painting the face of a known person upon a historical figure. First, it is a jester in place of a philosopher-or, if we pay attention to the material construction of the painting, a philosopher appended on a jester. And second, the presence of said jester deserves to be understood beyond a superficial level, as the presentation of Democritus does not erase the identity of the sitter. Amplification moves in both directions: the Greek philosopher is brought forth and made both tangible and relevant, while Pablo de Valladolid, and indeed his occupation as a courtly entertainer, are astutely elevated. The choice of presenting a doubling is hardly happenstance. By adding the attributes of Democritus, namely the pointing and the globe, Velázquez is able to create a

38. Fernando Marías, "El género de Las Meninas: Los servicios de la familia," in Otras Meninas, ed. Fernando Marías (Madrid: Siruela, 1995), 258-61.

39. Bouza, Locos, enanos y hombres de places en la corte de los Austrias (Madrid: Temas de Hoy, 1996), 131-53; Frieder, 5; Laura Bass, The Drama of the Portrait (University Park: Pennsylvania State University Press, 2008), 111-12. 
direct and striking resonance between philosopher and jester. It is through the latter that the former emerges, not as a distant character but as a present and relevant figure (especially since the repainting altered the attributes but not the sitter's physiognomy). The trope, perhaps by then an uninspired platitude, ${ }^{40}$ thus gives way to a radical inquiry that confronts the viewers, their attitudes, and their political and intellectual identities. By articulating an additional layer of significance, Velázquez creates a hybrid figure through which philosophical questions persist across history, addressing the frailty of the human condition. Incorporating a visual strategy that is also deployed in paintings like his 1628 The Triumph of Bacchus or the 1657 The Spinners, Velázquez creates in the Democritus a liminal enclave where two different spatiotemporal and narrative subject matters are amalgamated. Unlike those paintings, Democritus avoids a dialectical tension between myth and fact, and past and present, by collapsing time and space. Democritus does not introduce a juxtaposition of figures and temporalities, but a synthetic embodiment of a transhistorical truth, which deftly befits its philosophical (and not mythic) content. Much like The Spinners, Democritus appears to evince a humanist position that elevates the subject of the painting, in this case by staging a learned encounter in which the viewer dialogues with a lowly individual - a practice that connects Democritus with other paintings, like his neo-stoic Aesop. ${ }^{41}$

Not only does the presence of Pablo de Valladolid (or at least of an individual reminiscent of a jester) create a tangible sense of reality, it allows for the painting to be contextualized around the notion of those who speak the truth; who say what others cannot. ${ }^{42}$ The artist is then not making changes in the composition "before achieving his image of the philosopher" ${ }^{43}$ but rather

40. Rico, 61 .

41. Charles de Tolnay, "Velázquez’s Las Hilanderas and Las Meninas (An Interpretation)," Gazette des Beaux-Arts 35 (1949): 32-34; Brown, Velázquez, 251-53; Madlyn Kahr, Velázquez: The Art of Painting (New York: Harper \& Row, 1976), 211; Julián Gállego, “Aesop," in Velázquez, ed. Domiguez et al. (New York: Metropolitan Museum of Art, 1989), 208; Giles Knox, The Late Paintings of Velázquez: Theorizing Painterly Performance (Burlington: Ashgate, 2009), 59-118.

42. Bouza addresses the liberties conferred to buffoons in Locos, enanos y hombres de places, 25-38, and "Modern Rogues and Ancient Philosophers", 205-12. It has been elsewhere noted that Velázquez's interest in jesters and picaresque characters percolated through his depiction of other elevated subjects such as Aesop or Menippus: see López-Rey, 83-86; Brown Velázquez, 163; Georgievska-Shine and Silver, 186-87. 43. López-Rey, 278. 
supplementing the figure of Pablo de Valladolid in order to visually articulate the period association of philosophers and buffoons. ${ }^{44}$ Through his repainting, Velázquez has not "obliterated the hand" of the sitter; ${ }^{45}$ he has given it direction and, by doing so, has re-contextualized the smile. Strikingly, the commonplace intimacy of the exchanges between buffoons and the upper classes remains. ${ }^{46}$ Hence, though the subject matter of the painting has been seemingly modified, ${ }^{47}$ this change is not an absolute but rather an addition. Even if the subject matter has been decentred, the figure of the jester persists-neither his personhood nor his employment has vanished. ${ }^{48}$

The confident familiarity and casualness of an encounter with a court entertainer raises important questions regarding the psychological depth of the sitter. The Spanish painter famously highlighted the human complexity in his portraits of aristocratic, courtly sitters and of commoners, from his palatial dwarfs and jesters to his assistant (of Moorish descent and his once slave) Juan de Pareja. ${ }^{49}$ The transformation of the painting into a depiction

44. Bouza, "Modern Rogues and Ancient Philosophers," 207.

45. Brown, Velázquez, 57.

46. Fernando Bouza, "Sembanza y aficiones del monarca: Música, Astros, libros y bufones," in Felipe IV: el hombre y el reinado, ed. J. Alcalá-Zamora (Madrid: Centro de Estudios Europa Hispánica, 2005), 33.

47. Bouza, "Sembanza y aficiones del monarca," 33.

48. To extrapolate George Mariscal's argument regarding seventeenth-century Spanish literature, early modern culture produces subjects through multiple systems of signification and power relations: "to say that the subject is divided or decentered because it is positioned, implicated, or inscribed in a wider context is not to say that it no longer exists, or even that it is hopelessly subjugated." George Mariscal, Contradictory Subjects: Quevedo, Cervantes, and Seventeenth-Century Spanish Culture (Ithaca: Cornell University Press, 1991), 6.

49. On the often discussed topic of Velázquez’s psychological insight see, e.g., Jonathan Brown, Collected Writings on Velázquez (Madrid: Centro de Estudios Europa Hispánica, 2008), 40, 45; Jonathan Brown, Painting in Spain: 1500-1700 (New Haven: Yale University Press, 1998), 126; Pérez Sánchez and Gállego, Velázquez, 222; Betty Adelson, The Lives of Dwarfs: Their Journey from Public Curiosity toward Social Liberation (New Brunswick: Rutgers University Press, 2005), 149-51. On the painter's portrait of and relationship with Juan de Pareja, see Victor Stoichita, "El retrato del esclavo Juan de Pareja: semejanzas y conceptismo," in Velázquez, ed. Alpers et al. (Madrid y Barcelona: Fundación Amigos del Museo del Prado 1999), 367-81; Svetlana Alpers, The Vexations of Art: Velázquez and Others (New Haven and London: Yale University Press, 2005), 180; Carmen Fracchia, "Metamorphoses of the Self in EarlyModern Spain: Slave Portraiture and the Case of Juan the Pareja," in Slave Portraiture in the Atlantic World, ed. Agnes Lugo-Ortiz and Angela Rosenthal (Cambridge: Cambridge University Press, 2013), $147-70$. 
of Democritus heightens the psychological significance, placing the canvas within a philosophical framework and re-enacting the encounter in the ancient narrative between Democritus and those who came to see him. As the viewer follows the philosopher's gesture, the object of Democritus's laughter unfolds. To understand Velázquez's process of addition it is then necessary to turn our attention to the sphere, an object that is not merely signifying the trope of Democritus at an iconographical level.

\section{A sphere}

A transitive smile: Democritus's hand points at the sphere, indicating that it is the object of his amusement. What the sphere signifies or connotes is not as clear as it may seem. The scholarship on the painting reflects upon this issue: "If the painting represents a geographer, the globe is literal, a tool of the geographer's trade. If it represents Democritus, human nature has been globalized." ${ }^{50}$ Yet the doubt regarding subject matter remains unfounded: what professional laughs at the tools of his trade? The sphere invokes the planet itself, Earth. But the globe is a mediator trope, a metaphor, and not the object of Democritus's laughter in itself. The globe is but a signifier. This is the Democritus that appears in Erasmus and Montaigne: the Greek philosopher who laughs at the folly of humanity in its general sense. Most images of Democritus clearly emphasize this meaning, depicting an abstracted globe without concrete or accurate geography. In doing so, these paintings implicitly borrow from a Christian pictorial tradition that makes use of such abstracted images. Democritus is remarkable, as it not only portrays a readable (though abstruse) geography but also presents the globe as a physical artifact, the type of object learned men would have had in their studios. Bouza has connected pictorial representations of Democritus over a globe with what he has acutely described as a "Senecan" interpretation (manifested via authors like the Jesuit Daniello Bartoli) in which the puny world is seen from the heaven above. ${ }^{51}$ Now this is true of the Democritus to a certain extent, as the figure's hand hovers above the globe but, importantly, Velázquez's painting avoids the idea of a quasi-metaphysical figure soaring in the heavens. Velázquez depicts a materially concrete globe that exists within the reality of the viewer as an object,

50. Charles A. Knight, The Literature of Satire (Cambridge: Cambridge University Press, 2004), 2.

51. Bouza, "Modern Rogues and Ancient Philosophers," 207. Bouza quotes Daniello Bartoli, Delle due eternità dell'houmo. L'una in Dio, l'altra con Dio. Considerationi (Rome: Ignazio Lazzari, 1675), $246-47$. 
unlike an ethereal and abstracted globe. In doing so, the Spanish painter reflects on his own interest in geography, evinced by the presence of a range of books concerning cartography, travel, and navigation in his library. ${ }^{52}$

In the painting, the sphere operates as a practical object, an actual map of the Earth, but spheres in early modern Europe most commonly appear as iconographic signifiers. There is an established tradition in the sixteenth and seventeenth centuries that links images of globes to imperial power, spheres being pervasively presented as political symbols. The many well-known examples of this iconographical usage include Charles V, whose humanist circle successfully imprinted an inerasable image - the Columns of Hercules framing a globe-on a generation of Spaniards, as J. H. Elliott put it. ${ }^{53}$ The use of spheres by the emperor was adopted by his allies. Notably, Cosimo de' Medici consciously made use of such political iconographical programs to reference those of Charles V, upon whom Cosimo's rule depended..$^{54}$ Within the larger European context, we are reminded of objects such as Benvenuto Cellini's 1515 silver medal for Francis I, which shows the terrestrial and heavenly spheres with the inscription "unos non sufficit orbis" (interestingly, taken from Juvenal's Satire X), heralding global aspirations..$^{55}$ Through the sixteenth century, in fact, a consistent rhetorical program reified the intertwining of political ambitions and images of the world's sphere, especially after Clement VII signed, on 1 March 1530, "to sanction the imperial orb as, 'the image of the entire universe." ${ }^{56}$ As we come closer to Velázquez's time, we thus encounter an apparatus of representation firmly uniting globes and monarchical rhetoric. Philip IV himself was not only a monarch

52. Ángel Aterido, "The Culture of Velázquez: Reading, Knowledge and Social Connections," in Velázquez's Fables: Mythology and Sacred History in the Golden Age, ed. J. Portús Pérez (Madrid: Museo del Prado, 2007), 91.

53. J. H. Elliott, Spain, Europe, and the Wider World 1500-1800 (New Haven and London: Yale University Press, 2009), 133-34. This usage is illustrated by Parmigianino's 1529-30 Allegorical Portrait of Charles where the world is given to Charles by a boy Hercules. For examples of the pervasive use of the image in royal tapestries, see Antonio Dominguez Ortiz et al., Resplendence of the Spanish Monarchy (New York: Metropolitan Museum of Art, 1991), 55-67.

54. Francesca Fiorani, The Marvel of Maps: Art, Cartography and Politics in Renaissance Italy (New Haven: Yale University Press, 2005), 33, 38.

55. Lisa Jardine and Jerry Brotton, Global Interests: Renaissance Art between East and West (Reaktion: London, 2000), 48.

56. Fiorani, 39. 
acutely interested in his dynastic lineage, but also a king who collected armillary spheres, like the well-known design by Antonio Santucci. Moreover, despite the multiple political problems that emerged during his reign, the aspiration of the Spanish monarch became quite palpable in his desired epithet, El Rey Planeta. Hence, the connection between spheres and monarchy was quite present in the court of Philip IV, and it would have been impossible for Velázquez or any court figure to be unaware of such connotations. This connection is palpable in the 1632 royal portrait Don Baltasar Carlos and Dwarf, a painting in which the court entertainer holds an apple and a jewelled rattle-a visual play on the scepter and orbis mundi iconography in which the dwarf has been seen as enacting a parody of imperial power. ${ }^{57}$

Velázquez's Democritus, nonetheless, does not provide us with a sphere that is easily seen as an iconographical motif. Velázquez's sphere seems too plain and utilitarian an object to be worthy of political significance. As a signifier, the sphere in Velázquez's painting is small when compared to a sphere that the monarch would have exhibited. It is a practical object, not an item worthy of royal display. Placed beside the books, on the table, the sphere seems simply an object of study, the tool of a learned man. In this sense, the sphere subtly embodies a series of resonances while maintaining a degree of distance: its iconographic connotations are only indirectly evoked.

To be clear: I am not arguing that the presence of a cartographic globe is in and by itself what makes Velázquez's painting unique, or that the accurate geography intrinsically invokes a critical framework. Nor is Velázquez’s the first painting of the philosopher to include a cartographic globe. Two well-known paintings of Democritus and Heraclitus had already incorporated an accurate depiction of the period's geographical knowledge: Bramante's in 1487 and Rubens's in 1603. But Velázquez's painting is quite exceptional insofar as the globe appears as a mundane, physical object rather than an imaginary sphere. This is quite palpable in comparison to Rubens's paintings, where the sphere appears as a metaphorical symbol set in a landscape. What is ultimately most striking in Democritus is how the globe is presented. Although the geography is difficult to read, the sphere shows Spain and the Atlantic world. ${ }^{58}$ The sphere

57. Frieder, 6. See also Jonathan Brown, Velázquez: Painter and Courtier, 83; Bass, 110, 155n35.

58. Benjamin Schmidt and Richard Kagan, “The World of Early Modern Spain: Empire and its Anxieties in the Golden Age," in Spain and the Age of Exploration, 1492-1819, ed. Chiyo Ishikawa (Seattle: Seattle Art Museum in association with University of Nebraska Press, 2004), 71, exhibition catalogue. 
has been rotated to display Spain and the coast of West Africa on the top, while the Americas appear in the bottom, surrounded by shadows and difficult to perceive with exactitude. This obscuration, which appears so ordinary in the depicted object (just a shadow following the naturalistic lighting of the painting, after all), becomes significant in the Habsburg context of the painting. Charles V's "empire on which the sun never sets" is now literally engulfed by darkness. This positioning also affects the map's readability, the facility with which the map gives itself to its viewers. Turned, the globe appears as an item initially comprehended as a sphere showing the world and its geography, while simultaneously complicating visual access to the concrete location of geographic elements within the map. The viewer's sense of orientation is displaced, and heads tilt slightly to the side in order to decipher the map. ${ }^{59}$

\section{Laughter}

"Laughter is divided in two parts, because there is true laughter and false laughter," wrote the humanist doctor Francisco López de Villalobos in his 1543 Libro intitulado los problemas de Villalobos. ${ }^{60}$ The book was part of Velázquez's personal library. ${ }^{61}$ True laughter, Villalobos argues, is a human characteristic that separates us from other animals - though he quickly argues that crying is ultimately more intrinsic to the human experience than laughter, as we are born crying but do not laugh until forty days after birth. ${ }^{62}$ In his study, Villalobos is hesitant to address true laughter: in order to explain it, one would have to

59. David Morris notes that thinkers since Plato have been aware that "the topology of residing and our sense of orientation, via our bodies, open into an ethical dimension, and so too does our sense of space." David Morris, The Sense of Space (Albany: State University of New York Press, 2004), 154-55.

60. "La risa se divide en dos partes, porque hay risa verdadera et risa falsa." Francisco López de Villalobos, "Capítulo VII.-De la definición de la risa y de su division," in Libro intitulado los problemas de Villalobos, que trata de cuerpos naturales y morales, dos diálogos de medicina y el tratado de los tres grandes, una canción y la comedia Anphitrion (Zamora: Juan Picardo, 1543). Republished in Curiosidades bibliográficas, Biblioteca de Autores Españoles 36, ed. A. de Castro (Madrid: Rivadeneyra, 1855), 454-55. 61. Ruiz Pérez, La Biblioteca de Velázquez, 56-57. On Velázquez’s library see also Aterido, “The Culture of Velázquez."

62. "La verdadera es una propiedad que tiene el hombre en cuanto es hombre, diferente de todos los otros animales, que ninguno de ellos es risible sino el hombre; aunque á mi parecer mas cierta propiedad del hombre es el llorar que el reir, porque lloran en nasciendo, y algunas veces dentro del vientre, y la risa comunmente no viene hasta los cuarenta dias después del parto.” López de Villalobos, “Capítulo VII.” 
describe the substance of vital spirit and open the curtains that enclose the heart. ${ }^{63}$ True laughter is too complex to be explained. In contrast, false laughter is nothing but a shallow simulation created to mislead. ${ }^{64}$ False laughter entails sophistry. In an acerbic tone, Villalobos condemns false laughter as "a passion and property of a vermin called the court. This is an animal that is always laughing without a desire to do so; it has two or three thousand mouths." 65 False laughter, the idle laughter of the courtiers, is performed without thought, at times even before those courtiers know the object of their laughter. Villalobos clarifies the power dynamics involved in the performance of laughter: when princes laugh, everybody in their presence laughs as well. ${ }^{66}$ In della Porta's previously mentioned Della fisonomia, which makes references not only to Democritus but also to Plato, Aristotle, and Seneca, the conclusion is similar,

63. "En las causas naturales desta risa no me entrometo agora, porque sería menester declarar la hechura del corazón, y de las telas y cortinas de que está cercado, y declarar la substancia del spíritu vital que está aposentado en el seno izquierdo del corazon, y declarar la impresion que este hace en los miembros espirituales cuando con el súbito gozo sale a hacer cosquillas en ellos. Y como la materia destas cosas es muy larga, y ha menester muchos principios y fundamentos para entendellas no es lugar este para tratar della; en otra parte tengo escripto lo que yo desto alcanzo, protestando que no he visto sobre ello en escripto cosa que me satisfaga." López de Villalobos, "Capítulo VII."

64. "La risa falsa es una simulación de risa y de gozo que fingen unos hombres para engañar á otros y para darles a entender lo que no es." López de Villalobos, “Capítulo VII.”

65. "Esta risa es pasion y propiedad de una alimaña que se llama la corte. Este es un animal que siempre se anda riendo, sin haber gana de reir; tiene dos ó tres mil bocas, todas muertas de risa, unas desdentadas como bocas de máscaras, otras colmilludas como de perros, otras grandes calaveras, que descubren de oreja á oido, otras fruncidas como ojales de botones, otras barbudas y otras rasas, otras masculinas y otras femininas, otras vocingleras y otras roncas, otras gruñidoras y otras gomitonas, otras á boca cerrada y otras regañosas, otras enrubiadas y otras teñidas de negro. Cosa es cierto de ver, no considerando que son muchos hombres, sino muchos miembros de un animal.” López de Villalobos, “Capítulo VII."

66. "Porque los hombres de corte, como son mas convenables y mas ociosos que la otra gente, tienen en gran precio ser donosos, y es lisonja entre ellos reírse los unos de lo que dicen los otros, con condición que se lo paguen en lo mismo. Y algunos hay que cuando no hallan quien acuda con la risa á lo que ellos dijeron, riénselo ellos. Otros hay que antes que comiencen a contar el donaire se rien antemano, y otros que en tanto que lo dicen se caen de risa. Esto es convidar a risa a los oyentes, como si dijesen yo bebo a vos, y para que sepan que es cosa de reir y que no sean necios. Y estos por la mayor parte quedan después del donaire tristes y frios, salvo si son príncipes ó grandes privados; porque estos en comenzando á reir, hacen á todos los otros caerse de risa, unos sobre las arcas y otros sobre los bancos, otros sobre los hombros de sus compañeros, otros llorando de risa que sus ojos se tornan fuentes perenales, otros juran que les duelen las arcas, otros se le desencajan las quijada?” López de Villalobos, “Capítulo VII.” 
and histrionic courtly laughter is lambasted. The laughter of the courtier is nothing but a calculated performance, and one that "abounds in the mouth of fools." ${ }^{67}$

Velázquez depicts not exaggerated laughter but a smile. There is a sense of composure in the figure's expression, and it is not the affected laughter that classical sources and their literary interpreters would have us imagine. ${ }^{68}$ Although (or perhaps because) depictions of Democritus and Heraclitus were constructed using established attributes, painters' choices on how to handle these attributes are significant. In the case of Democritus, the choice between a frenzied grin and an affable smile establishes much of the psychological state given to the philosopher and the assumed response to his viewers. Scholars have noted, for example, that Rubens, in his 1603 painting of the two philosophers, consciously ascribed "Christ-like qualities for Democritus, who is not really laughing." ${ }^{\prime 9}$ Given the popularity of the two philosophers in the visual arts and literature, painters were able to subtly shift their presentation while assuming that audiences were well aware of the laughter and crying dichotomy. Throughout the seventeenth century, artists would precisely manipulate Democritus's gesture, from unrestrained laughter to quiet smile, while retaining the trope.

Velázquez is presenting us with the image not of a madman but of a jester-that is, someone who can escape the sycophantic performance of laughter in order to articulate a genuine, truth-bearing gesticulation. ${ }^{70}$ In the Nicomachean Ethics, a book that Velázquez owned, Aristotle criticizes those who make a joke of anything as being mere buffoons, as distinct from the virtues of wit. ${ }^{71}$ Though a buffoon by profession, the character of Democritus is, in Aristotelian terms, like the witty gentleman who jests with good taste: ${ }^{72}$ a genuine and spontaneous reaction, but moderate nonetheless. Indeed, a

67. "Il riso abonda nella bocca de' stolti." Della Porta, Della fisionomia dell'huomo, book 2, chapter 18, "Del Riso."

68. The affable smile of Velázquez's Democritus can also be contrasted with the histrionic and sinister grimace found in the contemporary paintings of the same subject made by Johannes Moreelse, who depicts the philosopher in a manic state.

69. Lepage, 118. See also Wind, "The Christian Democritus."

70. García Gómez, 179-80.

71. Aristotle, Nicomachean Ethics, 1128a.

72. Aristotle, 1128a. Bouza, Locos, enanos y hombres de placer, 94-98. 
jester's profession makes him quite aware that there is a play of limits within courtly performances and, ultimately, a temperate smile invokes truthfulness where a histrionic laughter can only imply sycophantic mendacity. Velázquez, who also owned Castiglione's Courtier, likely understood that decorous jokes, jests, and witticisms should not lead to embarrassment or humiliation but must remain tasteful. ${ }^{73}$ There is nothing vulgar about Democritus: he looks at the viewers, confidentially and with a warm smile, plainly pointing towards the globe. A silent joke, the pointing is an innuendo created by an educated man. Unlike Velázquez's other images of jesters, often portrayed in serious stances that bespeak of deeply contemplative and even assertive qualities, the jester in Democritus actually appears smiling (though this gesture does not take away from the psychological attentiveness of the depiction). At the same time, the painter ensures that the laughter is not seen as buffoonery, obsequiousness, or a display of vulgarity. In this sense, Velázquez's Democritus appears in contrast to a certain courtly aristocratic tendency towards histrionic responses (a practice that López de Vega sternly censures in his Héraclito and Demócrito, as do plays like Alonso de Castillo Solórzano's 1637 El mayorazo figura and, to a certain extent, Félix Lope de Vega's 1613 La Dama Boba). ${ }^{74}$ This does not denote abhorrence by the part of seventeenth-century Spaniards towards dissimulation, but rather an awareness of the difference between social performance and affectation, between a cultivated, "natural" mode of selfrepresentation and crude exaggeration. ${ }^{75}$

Simon Critchley writes, "Humor is an exemplary practice because it is a universal human activity that invites us to become philosophical spectators upon our lives." ${ }^{76}$ And it is this value of humour that Democritus requests. We may call it a pedagogical smile, rather than comic or satiric, though one cannot forget that the lines between satiric, burlesque, festive, comic, and jocular are not always clearly demarcated, especially in seventeenth-century Spain. ${ }^{77}$ Still, the learned and moral qualities of Democritus's laughter do seem to introduce

73. Joel Snyder, “Las Meninas' and the Mirror of the Prince," Critical Inquiry 11.4 (1985): 539-72. Alpers, The Vexation of Art, 156-57; Bouza, Locos, enanos y hombres de placer, 63.

74. Bouza, "Modern Rogues and Ancient Philosophers", 222-23; Bass, 27-41.

75. Bass, 40-41, 130.

76. Simon Critchley, On Humor (London: Routledge, 2002), 18.

77. Antonio Azaustre Galiana, "Algunos aspectos de la risa en la prosa burlesca de Quevedo," in Demócrito áureo, ed. I. Arellano and V. Roncero (Seville: Renacimiento, 2006), 11-50. 
a type of educated response that moves away from the merely jocular. ${ }^{78}$ In this very sense, Denis Cosgrove has stressed that the ruins of ancient amphitheatres were testament to the vanitas of imperial endeavours-a notion that links the image of the world as a theatre to the two philosophers' faces, which act as masks symbolizing comedy and tragedy. ${ }^{79}$ But any categorization into genres quickly misdirects our attention from the figure's smile and the trope of Democritus's laughter.

By focusing the interpretation of the painting via laughter, rather than genre, it is thus possible to avoid a stipulated end, whether positive (comedy) or tragic (satire). Instead, the value of Democritus's laughter is pedagogical and therapeutic, ${ }^{80}$ and it is the viewers' actions that will determine the potential outcome, and with it, the genre of the performance. The interest of the ethical qualities of laughter as a means to correct vices pervaded the poetics of early modern Spain. ${ }^{81}$ More pertinently still, Juan Huarte, in the second proem to the reader of his 1575 Examen de ingenios para las ciencias, which granted him European renown, accentuates the didactic quality of the wise Democritus. ${ }^{82}$ Huarte narrates how Democritus taught Hippocrates that, from the cradle to the grave, man is ill from ignorance. As a consequence, the world is a madhouse where life is but a comedia graciosa. Huarte elucidates:

Don't you see that the entire world is ill? Some buy horses and others, dogs; they want to rule over many and cannot rule in itself; they take a woman and soon disown her; they love and then loath; they make haste to have children, and when they are old they throw them away from home. [...] What desire is this that in nothing differs from dementia? Civil wars

78. Ignacio Arellano, "Las máscaras de Demócrito," in Demócrito áureo, ed. I. Arellano and V. Roncero (Seville: Renacimiento, 2006), 335-45.

79. Denis Cosgrove, "Globalism and Tolerance in Early Modern Geography," Annals of the Association of American Geographers 93.4 (2003): 852-70.

80. Arellano, "Las máscaras de Demócrito," 346.

81. Arellano, "Las máscaras de Demócrito," 336-39.

82. "No delira Democrito, sino que sabe en extremo y nos enseña." Juan Huarte, "Segundo proemio al lector," Examen de ingenios para las ciencias (Baeza: Juan Bautista de Montoya, 1575). 
are made, falling out with peace; they dethrone kings, they replace them; they kill men; they dig the earth in search for gold..$^{83}$

Huarte's account thus identifies the object of Democritus's laughter, namely the madness of men, which is exemplified among other ethical offenses by follies endemic to political ambitions. Laughter is not ultimately emphasized in itself, but presented as a means to an end. Huarte finishes the narrative by highlighting the educational function of the philosopher's laughter. Furthermore, Joubert's Traité $d u$ Ris, in describing the encounter between Democritus and Hippocrates, had precisely highlighted the pedagogical qualities of the Greek philosopher: "he alone was able to make all the men of the world wise and prudent." ${ }^{34}$

The philosophical and pedagogical message of Democritus discloses contemporary concerns. Its political significance remains central, especially given the number of critics of the crown who used artistic means to express political opinions. Certainly, the state of satire was in good health in the Spain of the seventeenth century, most likely as a consequence of the period's political uneasiness. ${ }^{85}$ Despite moving against the ideological program of its time, which utilized culture "to protect and perpetuate an existing semiotic and ideological regime," Velázquez's painting is a much less scathing attack on Spanish ideology than many a contemporary denunciation. ${ }^{86}$ In other words, the idea of Democritus requesting a critical reading of the political realities of the period would be on par with the larger Spanish cultural realm of the seventeenth century, where voices of dissatisfaction were conspicuous. Although contemporary scholars have noted that the economic situation of

83. “'Acaso no adviertes que todo el mundo está enfermo? Unos compran perros y otros caballos; quieren mandar sobre muchos y no saben mandar en sí; toman mujer y a poco la repudian; aman y luego aborrecen; afanan por tener hijos, y de mayors los echan de casa [...] ¿Qué absurdo afán es éste que nada difiere de la demencia? Se hacen guerras civiles, reñidos con la paz; deponen reyes, los reemplazan; matan hombres; cavan la tierra en busca de oro." Huarte, "Segundo proemio al lector."

84. Joubert, 107-08. Joubert links both the laughter and the crying to the melancholic humour, which creates anguish and sorrow in the mind when it is cold and gives assurance and delight when it is hot.

85. Mercedes Etreros, La sátira política en el siglo XVII (Madrid: Fundación Universitaria Española, 1983), 16.

86. Bradley J. Nelson, "Emblematic Representation and Guided Culture in Baroque Spain," in Culture and the State in Spain: 1550-1850 (New York: Garland, 1999), 157-93, 157. 
seventeenth-century Spain was not as dire as had traditionally been assumed, ${ }^{87}$ the cultural circles of the period were critical of Philip IV's politics. Authors such as Luis de Góngora, Lope de Vega, Francisco de Quevedo, Tirso de Molina, and Pedro Calderón de la Barca all "worked into their writings a delicate critique of Castillian Decline." ${ }^{88}$ Góngora went so far as to explicitly attribute greed as the motivating factor underlying the voyages of Columbus and Magellan, and his Soledades have been recently interpreted as calling attention to the inadequacy of both maps and their ideologies. ${ }^{89}$ And Quevedo is widely believed to have written two poems that directly castigated the government of Philip IV and its international demise, the 1625 sonnet "Al mal gobierno de Felipe IV" ("To the Bad Government of Philip IV") and the 1641 satire "Sobre el estado de la monarquía" ("About the State of the Monarchy"). ${ }^{90}$ Despite these texts, it is

87. Richard Kagan, "Prescott's Paradigm: American Historical Scholarship and the Decline of Spain," The American Historical Review 101.2 (1996): 423-46. See also Gonzalo Anes, "La economía en la Europa del Siglo de Oro," in El Siglo de Oro de la pintura española, ed. Javier Portús (Madrid: Fundación Amigos del Museo del Prado/Mondadori, 1991), 263-72; Gonzalo Anes and Álvarez de Castrillón, "La España de Felipe IV: La decadencia," in Felipe IV: El hombre y el reinado, ed. José Alcalá-Zamora (Madrid: Centro de Estudios Europa Hispánica, 2005), 330; Antonio Domínguez Ortíz, Crisis y decadencia de la España de los Austrias (Ariel: Barcelona, 1969).

88. Ishikawa, ed., 71. Also Héctor Urzáiz Tortajada, "El desvergonzado en Palacio: los graciosos de las comedias mitológicas," Acotaciones 17 (2006): 9-44; Elliott, 139-48.

89. Ricardo Padrón, "Against Apollo: Góngora’s Soledad primera and the Mapping of Empire," Modern Language Quarterly 68.3 (2007): 363-93; See also Lorna Close, "The Play of Difference: A Reading of Góngora's Soledades," in Conflicts of Discourse: Spanish Literature in the Golden Age, ed. P. W. Evans (Manchester: Manchester University Press, 1990), 185; Crystal Anne Chemris, Góngora's Soledades and the Problem of Modernity (Suffolk: Tamesis, 2008). Góngora, in the 1609 En la fiesta del Santísimo Sacramento, writes about two black women, one of whom, named Clara (literally, Clear), is sad because the colour of her skin is impure. Her friend responds that she need not worry, because it is the soul, not the skin, which should be as white as teeth. This contrasts, for example, with Lope de Vega's Comedia famosa del el Santo Negro Rosambuco. See Victor I. Stoichita, "La imagen del hombre de raza negra en el arte y la literatura españolas del Siglo de Oro," in Herencias indígenas, tradiciones europeas y mirada europeas, ed. H. von Kiigelgen (Madrid and Frankfurt: Vercuert, 2002), 262.

90. Pedro Laín Entralgo, "La vida del hombre en la poesía de Quevedo," in La Universidad Complutense Cisteriana: Impulso filosófico, científico y literario Siglos XVI y XVII, ed. L. Jiménez Moreno (Madrid: Editorial Complutense, 1996), 330. See also Ignacio Arellano, Poesía satírico bulesca de Quevedo (Pamplona: Universidad de Navarra, 1984), 33; Carlos José Riquelme Jiménez, La administración de justicia en el Siglo de Oro: La obra de Francisco de Quevedo (Ciudad Real: Instituto de Estudios Manchegos, 2004), 30, 67. 
notable that political criticism, even towards the figure of Philip IV, need not imply absolute subversion or a revolutionary attitude. Calderón, for example, presented the monarch as an earthly divinity and defender of the faith in public spectacles while inserting veiled criticisms of the Spanish monarch's political leadership into plays performed within the privacy of the court. ${ }^{91}$ Such a position strongly resonates with Velázquez's painting: a private, learned criticism of moral qualities that seeks not to deride but to inform thought.

Sveltana Alpers has called for a nuanced consideration of Velázquez, arguing that his political participations_including his vehemence in joining the order of Santiago, or even his (now lost) pictorial commemoration of the expulsion of the Moors from the peninsula-do not restrict his paintings which, she argues, "offer something different." 92 Addressing the dual nature of Velázquez's pictorial dialogue with the monarchy, she posits: "one of the singular and willful results of his pictorial practice was an unsettling of the social order or, at least, of its representation." ${ }^{33}$ In fact, Democritus is not the only painting in Velázquez's career that raises a critical mirror to the period's political reality. Two ca. 1632-35 paintings of jesters, Don Juan de Austria and Barbarroja, have been associated with the military failures of Spain in the period, the Mantuan War of 1628-31 and the subsequent Franco-Spanish conflict of 1631-35. ${ }^{94}$ Seen against the backdrop of contemporary events, Laura Bass argues, the two paintings "are deforming mirrors" that "stage a dynamic play of reflections that unsettles the apparently strict rigidity and ideological security of the official Spanish Habsburg representation regime." ${ }^{95}$ In this sense,

91. Margaret Greer, “Los dos cuerpos del rey en Calderón: 'El Nuevo Palacio del Retiro’ y 'El mayor encanto amor," in Actas del X Congreso de la Asociación Internacional de Hispanistas, ed. A. Vilanova (Barcelona: PPU, 1992), 975-84.

92. Alpers, The Vexations of Art, 180.

93. Alpers, The Vexations of Art, 177.

94. Frieder, 15-16; Bass, 111-12. The two paintings are recorded as hanging in the private quarters of the Queen. Bass, 107. See also, Jonathan Brown and John H. Elliot, A Palace for a King: The Buen Retiro and the Court of Philip IV (New Haven: Yale, 2003), 165-66; Portús, "Velázquez as History Painter," 47, 66; Bouza, “Modern Rogues and Ancient Philosophers," 205-06.

95. Bass, 111. See also Bouza, Locos, enanos y hombres de placer, 161-62; Bouza, "Modern Rogues and Ancient Philosophers," 223-24. The metaphor of the mirror in Bass's study is especially relevant here given the presence of a pedagogical literary genre of political philosophy, the speculum principis. These manuals, whose best-known exponent is Castiglione's The Courtier, became popular in the Spain of the Siglo de Oro, as demonstrated by Diego de Saavedra Fajardo's 1640 Idea de un príncipe politico cristiano 
the tone in Democritus is not altogether foreign from his oeuvre, and it is one that the philosophical subject of the painting itself calls for. A Democritus seeking to engage with the viewer critically, appealing to current concerns and even anxieties, is not a figure necessarily undermining the official authority's political power or its ideology, especially if the goal is edification rather than ridicule.

\section{A viewer looks at Democritus, smiling, pointing at a globe}

Democritus's smile establishes emotional distance in order to ameliorate the tragic despair that would otherwise make us cry hopelessly, in the manner of Heraclitus. ${ }^{96}$ At the same time, the globe and the contemporary figure of a jester de-distances the interaction. The smile operates towards the viewer, for smile and laughter are infectious and intersubjective. ${ }^{97}$ But who is this viewer? On one level, the viewer is the patron who commissioned or purchased the panting: the Marquis de Carpio or another learned individual within the sphere of the Madrid court. To such an educated, contemporary viewer, the political significance of the painting would have been inescapable, and the face staring back would be one they knew well. But Velázquez's Democritus also exists in relation to the known narratives constructed around the figure of the Greek philosopher. In this sense, Bouza has argued that the viewer of Velázquez's canvas took the place of those who came to see Democritus: his joviality is aimed at the painting's spectators. ${ }^{98}$ Democritus laughs, but his laughter teaches viewers to reconsider their position in a space that intertwines geopolitical realities and existential choices.

Democritus presents a philosopher who is not just concerned with ethical improvement but whose questions operate in relation to authority and geography. Much like the Democritus in Juan Huarte, Velázquez's philosopher

or the various works on the subject written by Baltasar Gracián. These manuals of courtly self-formation show ideal qualities as well as revealing inadequacies, and authors like Saavedra explicitly acknowledge that the text may transcend the limits of decorum and range. See Snyder, 517n29; Alpers, The Vexations of Art, 156-58. On the relationship between Velázquez and Gracián, see also Aterido, 81-82.

96. Arellano, "Las máscaras de Demócrito," 356.

97. Michael J. Owren and Jo-Anne Bachorowski, "Reconsidering the Evolution of Non-linguistic Communication: The Case of Laughter," Journal of Nonverbal Behavior 27.3 (2003): 183-200.

98. Bouza, "Modern Rogues and Ancient Philosophers," 227. 
questions the vanity of power and global dominance. The cause of the laughter anchors the smile within a spatiotemporal reality-namely, the moment when the earth puts itself forth in its unfathomable broadness, which a map cannot comprise. Velázquez's Democritus points at the little globe humans have constructed-itself a puny and ephemeral object. Our coming to terms with the world, via cartography, may very well be factual. Yet in this objectivity, qualitative relationships have been abandoned. Democritus's smile operates in contrast to the cartography of the globe and its conditions of possibility, reminding the viewer of the unstated impossibilities that dwell at the margins of earthly control and, in turn, fomenting an ethical framework. The inviting smile-not a histrionic laugh of derision-brings the viewer into a process of inquiry. The jester smiles, truthfully yet moderately. Standing in front of the philosopher, we also encounter a lack: the absence of a crying Heraclitus leaves the spectator without the possibility of sorrow. Democritus stands alone, bringing forth a trans-historical, ethical question. So we smile back, reflexively, perhaps remembering that Democritus laughed at those who came to see him, hopefully reflecting on our existential and ethical emplacement. 